\title{
GAMBARAN RONGGA MULUT PADA LANSIA PEMAKAI GIGI TIRUAN SEBAGIAN LEPASAN DI PANTI WERDA KABUPATEN MINAHASA
}

\author{
${ }^{1}$ Fransisca F. Watuna \\ ${ }^{2}$ Mona P. Wowor \\ ${ }^{3}$ Krista V. Siagian
}

\author{
${ }^{1}$ Kandidat Skripsi Program Studi Pendidikan Dokter Gigi Fakultas Kedokteran \\ ${ }^{2}$ Bagian Farmakologi dan Terapi Fakultas Kedokteran \\ ${ }^{3}$ Program Studi Pendidikan Dokter Gigi Fakultas Kedokteran \\ Universitas Sam Ratulangi Manado \\ E-mail: fransiscafabiolawatuna@yahoo.co.id
}

\begin{abstract}
Removable partial dentures can be an alternative treatment for tooth loss in the elderly. Users of removable partial dentures without good treatment can cause a variety of changes to the conditions of hard tissue and soft tissues of the oral cavity which is the first driveway for human digestive system. In addition, the use of removable partial dentures in the elderly are particularly susceptible to the occurrence of disorders of the oral cavity. The purpose of this study is to provide a picture of the oral cavity in elderly users of removable partial dentures in elderly nursing home in Minahasa. This is a descriptive cross sectional study. This study used a total sampling method, with respondents is a 30 elderly users of removable partial dentures in elderly nursing home in Minahasa. The results showed that the presence of ulcers as a result of artificial teeth in the upper jaw 66.67\%, ulcers due to artificial teeth on the lower jaw 50\%, 30\% gingival redness, swelling of the gingiva $30 \%$, 36.67\% gingival bleeding, gingival recession at 46, 67\%, 50\% Denture stomatitis, angular celulitis $46.67 \%$, Plaque $43.33 \%$, 56.66\% calculus, caries $93.33 \%$. The research shows elderly users of removable partial dentures in elderly nursing home in Minahasa have a conditions change for hard and soft tissues of the oral cavity. Suggested the elderly to pay more attention to health and hygiene denture for more vigorous control the state of the denture and the state of the oral cavity in dentistry.
\end{abstract}

Keywords: oral cavity condition, elderly, dental removable partial dentures

\begin{abstract}
Abstrak: Gigi tiruan sebagian lepasan dapat menjadi salah satu alternatif perawatan terhadap kehilangan gigi pada lansia. Pengguna gigi tiruan sebagian lepasan tanpa perawatan yang baik dapat menyebabkan berbagai perubahan terhadap kondisi jaringan keras dan jaringan lunak pada rongga mulut yang merupakan jalan masuk pertama sistem pencernaan manusia. Disamping itu, pemakaian gigi tiruan sebagian lepasan pada lansia sangat rentan terhadap kejadian kelainan - kelainan pada rongga mulut. Tujuan dari penelitian ini yaitu untuk memberikan gambaran keadaan rongga mulut pada lansia pemakai gigi tiruan sebagian lepasan di panti werda Kabupaten Minahasa. Penelitian ini merupakan penelitian deskriptif cross sectional. Penelitian ini menggunakan metode total sampling, dengan responden sebanyak 30 orang lansia pemakai gigi tiruan sebagian lepasan yang ada di panti werdha Kabupaten Minahasa. hasil penelitian menunjukan bahwa adanya Ulser akibat gigi tiruan pada rahang atas $66,67 \%$, Ulser akibat gigi tiruan pada rahang bawah $50 \%$, Kemerahan gingiva $30 \%$, pembengkakan gingiva $30 \%$, pendarahan pada gingiva $36,67 \%$, Resesi pada gingiva 46,67\%, Denture stomatitis 50\%, angular celulitis 46,67\%, Plak 43,33\%, Kalkulus 56,66\%, karies 93.33\%, Kegoyangan 23,33\%. Hasil penelitian menunjukan lansia pengguna gigi tiruan
\end{abstract}


sebagian lepasan di panti werda Kabupaten Minahasa mengalami perubahan kondisi jaringan keras dan jaringan lunak pada rongga mulut. Disarankan para lansia untuk lebih memperhatikan kesehatan dan kebersihan gigi tiruan untuk lebih giat mengontrol keadaan gigi tiruan dan keadaan rongga mulut di dokter gigi.

Kata Kunci: kondisi rongga mulut, lansia, gigi tiruan sebagian lepasan

Lanjut usia adalah periode yang telah mencapai masa tua dalam ukuran fungsi dan juga telah menunjukan kemunduran sejalan dengan waktu. Lansia juga identik dengan menurunnya daya tahan tubuh dan mengalami berbagai macam penyakit. Pada keadaan lanjut usia biasanya terjadi penurunan tingkat kebersihan gigi dan mulut dan juga berkurangnya gigi geligi yang berakibat kehilangan gigi. ${ }^{1,2}$

Kehilangan gigi merupakan suatu keadaaan tanggalnya gigi individu dari soketnya yang disebabkan oleh pencabutan karena karies atau penyakit periodontal, trauma, dan penyakit sistemik. Kehilangan gigi ini biasanya terjadi pada lansia dan dapat mengakibatkan terjadinya gangguan pada fungsi pengunyahan, fungsi temporo mandibular joint (TMJ), dan psikologis yaitu estetika dan fungsi bicara. ${ }^{3}$

WHO melaporkan bahwa kehilangan gigi pada lansia cukup besar, yaitu prevalensi kehilangan gigi pada populasi usia 65-75 tahun di Prancis 16,9\% Jerman 24,8\% dan Amerika Serikat 31\%. Berdasarkan Penelitian yang telah dilakukan oleh Nimri (2004), ${ }^{4}$ di Jordania tentang kondisi rongga mulut pada lansia pemakai gigi tiruan lepasan dilaporkan adanya keluhan tidak puas dengan kondisi gigi tiruan yang digunakan karena menyebabkan lesi pada rongga mulut, rasa nyeri ketika memakai gigi tiruan, banyak pasien kesulitan dalam berbicara, gigi tiruan sering terjatuh pada saat makan dan berbicara, serta adanya akumulasi plak dan kalkulus pada gigi tiruan. Berdasarkan Riset Kesehatan Dasar (Riskesdas) 2013 Indonesia yang bermasalah pada gigi dan mulut sebesar 25,9\%, dan di Sulawesi Utara diketahui bermasalah pada gigi dan mulut sebesar $31,6 \%$, prevalensi kehilangan gigi pada kelompok umur 55 -
64 tahun sebesar 10,13\% dan pada usia $\geq 65$ tahun sebesar 17,05\%. Penyebab utama kehilangan gigi lansia di Indonesia adalah karies dan penyakit periodontal. ${ }^{3,4}$

Gigi tiruan lepasan akrilik dapat menjadi salah satu alternatif perawatan terhadap kehilangan gigi pada lansia. Gigi tiruan ini murah dan terjangkau, tetapi dapat menyebabkan berbagai perubahan pada rongga mulut terutama jaringan keras dan jaringan lunak yaitu karies dan penyakit periodontal, serta terjadinya perubahan patologik pada mulut, seperti kegoyangan gigi dan hyperplasia. ${ }^{4-6}$

Kabupaten Minahasa mempunyai 8 panti werda yaitu, 4 panti yang ada di Tondano, 2 panti yang ada di Kawangkoan, dan 2 panti yang ada di Langowan dari survei awal ada beberapa orang yang menggunakan gigi tiruan lepasan di tiaptiap panti werda yang ada. Berdasarkan latar belakang yang telah diuraikan maka peneliti tertarik melakukan penelitian ini, untuk melihat kondisi rongga mulut pada lansia pemakai gigi tiruan lepasan di panti werdha kabupaten Minahasa.

\section{METODE DAN BAHAN PENELITIAN}

Penelitian ini merupakan penelitian deskriptif dengan menggunakan rancangan cross-sectional study. Populasi penelitian adalah para lansia yang ada di 8 panti werda yang ada di Minahasa dengan jumlah orang 30 orang yang menggunakan gigi tiruan sebagian lepasan dan masih ada gigi tersisa.

Sampel yang akan digunakan pada penelitian ini menggunakan teknik total sampling. Data yang diambil dianalisis secara manual dan diolah berdasarkan distribusi frekuensi yang disajikan dalam bentuk tabel 


\section{HASIL PENELITIAN}

Tabel 1. Distribusi Responden Berdasarkan Jenis kelamin

\begin{tabular}{crc}
\hline Jenis kelamin & $\begin{array}{c}\text { Jumlah } \\
\text { (n) }\end{array}$ & $\%$ \\
\hline Laki - laki & 8 & 26,66 \\
Perempuan & 22 & 73,34 \\
\hline Total & 30 & 100 \\
\hline
\end{tabular}

Tabel 2. Distribusi Responden Berdasarkan Usia

\begin{tabular}{ccc}
\hline Usia & $\begin{array}{c}\text { Jumlah } \\
\text { (n) }\end{array}$ & $\%$ \\
\hline $60-75$ & 18 & 60 \\
$76-90$ & 12 & 40 \\
\hline Total & 30 & 100 \\
\hline
\end{tabular}

Tabel 3. Keadaan Jaringan Lunak Pada Rongga Mulut

\begin{tabular}{|c|c|c|c|c|}
\hline Jaringan Lunak & Ada & Tidak & $\%$ & Total \\
\hline $\begin{array}{l}\text { Ulser akibat gigi } \\
\text { tiruan pada RA }\end{array}$ & 20 & 8 & 66,66 & 30 \\
\hline $\begin{array}{l}\text { Ulser akibat gigi } \\
\text { tiruan pada RB }\end{array}$ & 15 & 15 & 50 & 30 \\
\hline $\begin{array}{l}\text { Kemerahan pada } \\
\text { gingiva }\end{array}$ & 9 & 21 & 30 & 30 \\
\hline $\begin{array}{l}\text { Pembengkakan } \\
\text { gingiva }\end{array}$ & 9 & 21 & 30 & 30 \\
\hline $\begin{array}{l}\text { Perdarahan pada } \\
\text { gingiva }\end{array}$ & 11 & 19 & 36,66 & 30 \\
\hline Resesi pada & 14 & 16 & 46,66 & 30 \\
\hline gingiva & 15 & 15 & 50 & 30 \\
\hline Denture & 14 & 16 & 46,66 & 30 \\
\hline $\begin{array}{c}\text { Stomatitis } \\
\text { Angular } \\
\text { Celulitis }\end{array}$ & & & & \\
\hline
\end{tabular}

Tabel 4. Keadaan Jaringan Keras Pada Rongga Mulut

\begin{tabular}{crrrr}
\hline $\begin{array}{c}\text { Jaringan } \\
\text { keras }\end{array}$ & Ada & Tidak & $\%$ & Total \\
\hline Plak & 13 & 17 & 43,33 & 30 \\
Kalkulus & 17 & 13 & 56,66 & 30 \\
Karies & 29 & 1 & 96,66 & 30 \\
Kegoyangan & 7 & 23 & 23,33 & 30 \\
\hline
\end{tabular}

\section{BAHASAN}

Berdasarkan hasil penelitian menunjukan karakteristik responden berdasarkan usia pada Tabel 1 dan jenis kelamin pada Tabel 2, bahwa responden yang diteliti pada usia 60 - 75 tahun, dan 76 - 90 tahun, semuanya memakai gigi tiruan. Sedangkan berdasarkan jenis kelamin lebih didominasi oleh responden yang berjenis kelamin perempuan yaitu sebanyak 22 responden (73,34\%) dibandingkan laki - laki yaitu 8 responden (26,66\%).

Responden berdasarkan usia dan jenis kelamin yang memakai gigi tiruan sebagian lepasan lebih banyak pada usia 60 - 75 tahun, ini disebabkan karena di usia ini para lansia sudah banyak yang kehilangan gigi. Berdasarkan jenis kelamin lebih banyak pada perempuan, lansia berjenis kelamin perempuan lebih cenderung memakai gigi tiruan karena lebih memperhatikan penampilan, perempuan lansia juga lebih mementingkan estetis dan memiliki kesehatan rongga mulut yang lebih baik dibandingkan lansia berjenis kelamin laki - laki. Kondisi rongga mulut dan gigi tiruan yang buruk terjadi pada lansia laki - laki karena lansia laki - laki masih kurang memperhatikan penampilan. ${ }^{12}$

Hasil penelitian tentang gambaran keadaan rongga mulut menunjukan bahwa pada jaringan lunak rongga mulut lansia yang menggunakan gigi tiruan sebagian lepasan, sebagian besar responden mengalami ulser pada rahang atas akibat gigi tiruan sebanyak 20 responden (66,66\%) dan ulser akibat gigi tiruan pada rahang bawah sebanyak 15 responden (50\%). Hasil penelitian ini sejalan dengan penelitian yang dilakukan oleh Nimri di Jordania pada tahun 2004 tentang Kondisi Rongga Mulut Pada Lansia Pemakai Gigi Tiruan Lepasan, ulser akibat gigi tiruan pada rahang atas sebanyak 20 sedangkan ulser akibat gigi tiruan pada rahang bawah sebanyak 55. Beberapa penelitian lain di Eropa dan Amerika Utara menunjukan prevalensi ulser di mukosa mulut lansia, terutama pada lansia yang memakai gigi 
Watuna, Wowor, Siagian: Gambaran rongga mulut...

tiruan sebesar 25\%, kebanyakan ulser yang terjadi pada rongga mulut lansia biasanya berhubungan dengan sayap gigi tiruan yang terlalu panjang. ${ }^{12}$

Hasil lain yang diperoleh sehubungan dengan keadaan jaringan lunak rongga mulut yaitu denture stomatitis ada 15 responden (50\%). Hasil penelitian ini sejalan dengan penelitian yang dilakukan Nimri di Jordania pada tahun 2004, ada $28 \%$ responden yang mengalami denture stomatitis pada lansia pemakai gigi tiruan. Denture stomatitis terjadi oleh karena pemakaian gigi tiruan yang terus menerus sepanjang siang dan malam hari, biasanya juga disebabkan oleh spesies Candida yang adalah penghuni umum rongga mulut. ${ }^{12}$ Denture Stomatitis ini lebih cenderung terjadi pada rahang atas dari pada rahang bawah pada lansia pengguna gigi tiruan. ${ }^{27}$

Tabel 3 tentang gambaran keadaan rongga mulut menunjukan bahwa keadaan jaringan lunak pada rongga mulut ditemukan adanya angular celulitis pada 46,66\% responden. Hal ini sejalan dengan penelitian yang dilakukan oleh Nimri pada tahun 2004 tentang Kondisi Rongga Mulut Pada Lansia Pemakai Gigi Tiruan Lepasan, yaitu adanya 13 responden yang mengalami angular celulitis. Angular celulitis biasanya terjadi karena memakai gigi tiruan yang tidak memiliki retensi yang baik, dan biasanya terjadi pada lansia perempuan yang menggunakan gigi tiruan, C. Albicans, staphylococus aerus, atau keduanya dapat merupakan penyebabnya. Patogen ini di bawa ke sudut mulut melalui genangan saliva yang berulang dan kebiasaan sering menjilat sudut mulut. ${ }^{24}$ Penelitian yang dilakukan di China kondisi ini lebih sering ditemukan pada kelompok usia 60 tahun dan memiliki kecenderungan yang lebih tinggi terhadap perempuan. ${ }^{26,27}$

Hasil penelitian lain yang diperoleh sehubungan dengan gambaran jaringan lunak pada rongga mulut yaitu resesi gingiva sebanyak 46,66\%. Resesi gingiva biasanya terjadi akibat pemakaian gigi tiruan dengan desain yang buruk mengakibatkan perpindahan tepi gingiva bebas ke posisi apikal dari pertautan cementum enamel junction, resesi juga mengakibatkan hilangnya perlekatan dan terbukanya sementum, resesi dapat bersifat lokal atau umum, dan sering kali berkembang jika ada peradangan. ${ }^{24}$

Hasil penelitian lain yang diperoleh, tentang gambaran keadaan jaringan lunak pada rongga mulut yaitu 36,66\% responden yang mengalami perdarahan pada gingiva. Hal ini bisa terjadi karena desain gigi tiruan yang buruk. $^{24}$ Keparahan dari penyakit periodontal meningkat dengan sejalannya usia. Jaringan periodontal yang meliputi gingiva dipengaruhi oleh perubahan usia.

Hasil penelitian lain yang diperoleh pada jaringan lunak rongga mulut yaitu kemerahan pada gingiva 30\%, pembengkakan pada gingiva 30\%. Hal ini disebabkan karena penumpukan plak pada sekeliling gigi asli yang masih ada dan pada gigi tiruan dapat menyebabkan gingivitis. $^{22}$ Tetapi jika perawatan mulut dilaksanakan dengan baik dan gigi tiruan dibuat dengan berpegang teguh pada prinsip-prinsip desain, setelah jangka waktu pemakaian dua tahun, hanya sedikit saja kerusakan jaringan timbul. ${ }^{15,19,22}$

Hasil penelitian sehubungan dengan gambaran keadaan jaringan keras rongga mulut pada lansia yang menggunakan gigi tiruan sebagian lepasan, yang tertinggi yaitu adanya karies gigi 96,66\%. Resiko karies yang tinggi terjadi pada lansia pemakai gigi tiruan sebagian lepasan, Berhubungan dengan buruknya pemeliharaan rongga mulut oleh lansia dibandingkan dengan akibat secara langsung dari pemakaian gigi tiruan itu sendiri. $^{25}$ Tahun 1972, Hicklin dkk yang dkutip oleh Batizztusi menunjukan bahwa gigi penyangga menghadapi resiko yang lebih besar dibanding gigi yang lainnya. Ternyata $60 \%$ gigi penyangga mengalami karies sedangkan yang tidak berkontak dengan gigi tiruan sebagian hanya 24\% 
yang karies(dikutip dari Syahdinda R). ${ }^{27}$

Hasil penelitian lain yang diperoleh tentang keadaan jaringan keras rongga mulut, yaitu adanya kalkulus (56,66\%). Hal ini sejalan dengan penelitian sebelumnya yang dilakukan Nimri di Jordania, sebanyak 13 responden (6,5\%) yang mengalami kalkulus. ${ }^{7}$ Biasanya terjadi dari bakteri mati yang terjadi mineralisasi disertai sejumlah kecil protein saliva yang mengalami mineralisasi kalkulus juga terbentuk karena akibat proses dari klasifikasi plak. $^{24}$

Hasil penelitian lain yang diperoleh sehubungan dengan keadaan jaringan keras rongga mulut didapatkan plak $(43,33)$. Hasil penelitian ini sejalan juga dengan yang dilakukan Nimri di Jordania pada tahun 2004. Penumpukan plak biasanya terjadi pada lansia pemakai gigi tiruan sebagian lepasan yang biofilm bakteri sudah melekat kuat pada permukaan gigi tiruan maupun gigi asli yang tersisa, plak yang sudah lama sebagian besar terdiri atas anerob gram negatif. $^{24}$

Hasil lain yang didapatkan yaitu kegoyangan gigi (23,33\%). Kegoyangan gigi ini terjadi karena berkurangnya tinggi tulang alveolar pada lansia dan menjadi tumpuan dari gigi tiruan. ${ }^{12}$ Kegoyangan gigi merupakan hubungan antara daya yang kecil dan perpindahan gigi dalam jarak pendek untuk waktu yang lama. ${ }^{27}$

Perbedaan hasil penelitian ini dapat disebabkan mungkin karena tingkat kesadaran dari lansia pemakai gigi tiruan sebagian lepasan yang ada di Minahasa kurang memperhatikan kesehatan gigi dan mulut serta adanya penurunan fisik yang terjadi pada lansia untuk mengontrol gigi tiruan mereka kepada dokter gigi, dibandingkan dengan lansia yang ada di Jordania yang lebih memperhatikan kesehatan gigi dan mulut.

\section{SIMPULAN}

Hasil penelitian ini menunjukan bahwa pada jaringan lunak rongga mulut lansia yang menggunakan gigi tiruan sebagian lepasan mengalami ulser akibat gigi tiruan pada rahang 66,67\%, ulser akibat gigi tiruan pada rahang bawah $50 \%$, kemerahan gingiva 30\%, pembengkakan gingiva $30 \%$, perdarahan gingiva $36,67 \%$, resesi gingiva $46,67 \%$, denture stomatitis 50\%, angular celulitis 46,67\%. Selain itu, jaringan keras rongga mulut lansia pemakai gigi tiruan sebagian lepasan mengalami plak 43,33\%, kalkulus $56,66 \%$, karies 96,66\%, kegoyangan $23,33 \%$.

\section{SARAN}

Berdasarkan kesimpulan dan hasil penelitian di atas, beberapa hal yang penulis sarankan yaitu, menyarankan para lansia untuk lebih memperhatikan kesehatan dan kebersihan gigi dan mulut serta kebersihan gigi tiruan untuk lebih giat mengontrol keadaan gigi tiruan dan keadaan rongga mulut di dokter gigi agar mengurangi atau mencegah terjadinya kelainan pada rongga mulut, perlu adanya usaha preventif berupa penyuluhan kepada pengguna gigi tiruan sebagian lepasan khususnya lansia mengenai pentingnya perawatan gigi tiruan untuk kesehatan gigi dan mulut dalam mencegah adanya kelainan pada rongga mulut.

\section{DAFTAR PUSTAKA}

1. Rusilanti, Clara K, Ekawati W. Aspek Psikososial Aktifitas Fisik Dan Konsumsi Makanan Lansia Di Masyarakat. Gizi dan Pangan Jurnal. 2006; 1(2): 1-7

2. Sri. Hubungan Perilaku Dengan Status Kebersihan Mulut Dan Karies Gigi Pada Lansia. Ilmiah dan Teknologi Kedokteran Gigi FKG UPDM Jurnal. 2011; 8(1) : 32-32

3. Jubhari EH. Upaya Untuk Mengurangi Preparasi Gigi: Fung Shell Bridge. Dentofasial Journal; 2007 April; 1:6(1):27

4. Nimri M. Oral Condition f Geriatric denture wearers. RMS Journal. 2004; 11(1): 30-34

5. Departemen Kesehatan Republik Indonesia. Laporan Riset Kesehatan Dasar Nasional 2013. Jakarta: Badan 
Watuna, Wowor, Siagian: Gambaran rongga mulut...

Penelitian dan Pengembangan Kesehatan

6. Ketut R, Arifin. Hubungan Kesehatan Mulut Dengan Kualitas Hidup Lansia. Ilmu Gizi Jurnal. 2011; 2(2): 139-147

7. Ian E, Barnes, Angus W. Perawatan Gigi Terpadu Untuk Lansia. Jakarta: EGC, 2006: $43-46$

8. Syahdinda R. Kegoyangan Gigi Penyangga [skripsi]. Surabaya: Airlangga Univ.;2013

9. Langlais, Robert P. Atlas Berwarna Lesi Mulut Yang Sering Ditemukan. Jakarta: EGC, 2013: 68

10.Nurin F. Faktor-Faktor Penyebab Keilitis Angularis Pada Pasien Pengunjung Yang Berkunjung Ke Rumah Sakit Gigi dan Mulut Pendidikan Fkg Usu. [serial online] 2003 [citied 2014 Okt 4]; Available from: URL: http/www.researchgate.net/publication/ 50231706

11.Dharmatauma M, Koyama A, Kusumawati A. Tingkat Keparahan Halitosis Pada Manula Pemakai Gigi
Tiruan. Dentofasial Jurnal 2008;7(2): 108

12.Isabora B. Kebiasaan Memelihara Kebersihan Gigi Tiruan Pada Masyarakat Pemakai Gigi Tiruan Sebagian Lepasan Di Kelurahan Tanjung Rejo Kecamatan Medan Sunggal [skripsi]. Medan: Sumatera Univ.;2012

13.Syekhu. Evaluasi Kebutuhan Gigi Tiruan Pada Usia Lanjut [serial online] 2009 Sep 24 [cited 2014 April 28]; Available from URL: http:// wordpress.com

14.Chittaranjan B, Taruna, Sudhir, Bharath. Material And Methods For Cleaning The Dentures. [cited 20 Maret 2014] Available from: URL: http://www.nacd.in/component/simpled ownload/?task=download\&fileid=docs \%2Fpdf\%2F3\%2F1\%2F3.1.423.pdf

15.Featherstone JDB, Singh S, Curtis DA. Caries Risk Assessment And Management For The Prosthodontic Patient. J Pros 2011; 20: 2-9. 